\title{
Employee Performance Among Selected Tertiary Institutions: Evidence from Intrinsic Reward System
}

\author{
Modupe Olayinka Ajayi \\ Department of Project Management Technology \\ Federal University of Technology, P.M.B. 704, Akure, Ondo-State
}

\begin{abstract}
The study examined employee performance among selected tertiary institutions: evidence from intrinsic reward system. A descriptive survey research design was adopted for the study. The population of the study comprised the selected universities staff in Ado-Ekiti. A total of 360 structured questionnaires were administered to elicit information from the target respondents. Data gathered were analyzed using hierarchical regression models. The result showed that consultative participation significantly affect institutional stability as it was significant on institutional stability $(\mathrm{t}=-1.303, \mathrm{t}=5.429, \mathrm{t}=2.108, \mathrm{t}=6.365$ and $\mathrm{t}=3.078, \mathrm{p}<0.05)$ Thus, in conclusion, it was shown that all the constructs of the explanatory variable were significantly and positively related to employee performance of selected university in Ado-Ekiti.
\end{abstract}

Keywords: Intrinsic Reward, Employee, Performance.

DOI: $10.7176 / \mathrm{JESD} / 10-4-12$

\section{Introduction}

Reward management is a factor that needs to be looked into. This is necessitated by the various murmurs, go slows and strikes that occurs occasionally owing to unequal remuneration packages compared to relevant others. A good number of these Universities have poor or no reward management structure that often result to uncommitted employees. The aim of rewards management is to ensure that the value of employees and the contributions that they make in an organization is recognized and rewarded (Armstrong, 2012). This means that organizations use rewards management in order to fulfil and satisfy the needs of their employees as well as to ensure that they operate equitably and fairly. It has been believed commonly that the reward system helps the organization in keeping and retaining the efficient and competent employees. From among many other factors, reward systems have been identified as a most important factor to attain high level of Job satisfaction and best employee performance (Armstrong, 2012). Now a day's organizations require best reward system which appreciates the high performers by providing incentives and to motivate the low performers.

Shields, Brown, Kaine, Dolle-Samuel, North-Samardzic, McLean and Plimmer, (2015) stated that reward system should be based upon the differing needs of employees and should be the combination of monetary and non-monetary aspects. Reward management is one of the strategies used by Human Resource Managers for attracting and retaining suitable employees as well as facilitating them to improve their performance through motivation and to comply with employment legislation and regulation (Njanja, Maina, Kibet \& Kageni, 2013). As a result of these pressures, Human Resource managers seek to design reward structures that facilitate the organizations strategic goals and the goals of individual employees. Reward systems are very crucial for an organization (Maund, 2001). Rewards include systems, programs and practices that influence the actions of people. The purpose of reward systems is to provide a systematic way to deliver positive consequences. Fundamental purpose is to provide positive consequences for contributions to desired performance (Wilson, 2003). The only way employees will fulfill the employers dream is to share in their dream (Kotelnikov, 2010). Reward systems are the mechanisms that make this happen. They can include awards and other forms of recognition, promotions, reassignments, non-monetary bonuses like vacations or a simple thank-you. Torrington and Hall (2006) highlighted that when employees are rewarded, they get work done. Employers get more of the behaviour they reward, not what they assume they will automatically get from employees. Thus when employees surpass their target or exceed their standard they should be rewarded immediately as a way of motivating them. By doing this, employees directly connect the reward with behaviour and higher performance they have attained. Effective reward systems should always focus on the positive reinforcement. Positive reinforcement encourages the desired behaviour in organizations. This encourages employees to take positive actions leading to rewards. Reward programs should be properly designed in the organization so as to reinforce positive behaviour which leads to performance (Torrington \& Hall, 2006). Consequently, this study examined the effect of intrinsic rewards on employee's performance in private and public universities.

In view of the above fact, the study opine that is there any evidence that the schemes have the capability to complement quality of service delivery in terms of staff work output? What types of rewards and recognition are offered in the research Universities? How do they contribute positively to job performance and motivation? The lack of rewards will create an unpleasant environment, thus diminishing employees' work efforts and productivity which may cause them to with draw from their jobs. For these reasons, rewards are increasingly important. The 
main objectives of rewards are to attract and retain employees, to motivate employees to achieve high levels of performance, and to elicit and reinforce desired behaviour of the employees. Organizations often use financial rewards to prevent employee dissatisfaction and to motivate employees, although it may not be the best motivator for the long term. Therefore, it is evident that there is a knowledge gap to be filled. Therefore, the purpose of this study is to fill this gap by determining the effect of reward management strategy on employee performance/productivity in universities, and to understand how reward management works both in private and public universities.

\section{Literature Review}

An intrinsic reward actually fulfils employee's intrinsic factors or motivators and thus motivates him. Examples include; giving challenging task, involving in decision making process, giving a higher rank in hierarchy etc all these rewards do not required having increased salary as well and employee may be working at higher management rank without an increase in the salary and still more motivated. Bosco (2014) stated that "praise and recognition are the most efficient intrinsic reward that enhances employee's performance". Stoner and Freeman (1992) defined intrinsic rewards as the" psychological reward that is experienced directly by an employee. Intrinsic reward concerns with psychological development of employees (Williamson, Burnett \& Bartol, 2009). They are intangible benefits and include the characteristics such as autonomy, feedback and decision making participation (Hackman \& Oldham, 1976). The intrinsic reward system are created purposely to appreciate employees in form of selfesteem and related to their feeling of achievement and growth with organization. Employees are feel satisfy when they have accomplished something worth in work and orally appreciated by the organization.

According to Ajmal, Bashi, Abrar, Khan and Saqib (2015), intrinsic rewards are those which are non-cash rewards or not having any physical existence. For example, employee recognition, acknowledgement, professional growth, authority to immediate tasks, respect and appreciation. Deci (1971) defined that the intrinsic rewards had the great importance to integrate the commitment in employees. Organization provided the opportunities to employees by their performance for the recognition and acknowledgement as rewards and in result the employee emotionally attached with organization due to being recognized. The intrinsic rewards and social rewards found more helpful for employers to develop and construct the emotional attachment among employees towards organization goals and objectives (Ajmal et al., 2015).

Armstrong and Baron (2005) view employee performance as about encouraging productive discretionary behaviour with a goal to achieving human capital advantage. They continue to hold the belief that people are the most important source of competitive advantage, and recognize that, as opposed to other forms of competitive advantage resulting from improving factors such as design or process, the people factor is very difficult to reproduce or replicate, making it so valuable to organizations (Wambugu \& Ombui, 2013). Every manager, no matter what his or her role, knows that exceptional employee performance is critical in today's world (Ripley, 2008). A major responsibility of managers and supervisors is turning employee talent into performance. Managers who are effective at employee engagement have employees who are more likely to stay, more satisfied, more committed to the organization, and more productive. Managers and supervisors can increase productivity as a result of the employees' commitment that, in turn, can increase the amount of discretionary effort employees give to the job.

\section{Research Methods}

The study was carried in Ado-Ekiti, the capital city of Ekiti State. For the purpose of this study, descriptive research design was adopted and data was collected through administering of questionnaire to the target respondents. The study population of this research work consists of all the staff in Ekiti State University and Afe Babalola University Ekiti State. However, the total population of Staff of Ekiti State University is 2450 while in Afe Babalola University is 1395 . Therefore the total population for this researcher work is 3845.360 Staff of the selected universities were sampled using Yamane (1967) Sampling Model. Descriptive and inferential statistic were used employed where descriptive statistic was used to analyse the demographic information of the respondents while inferential statistic through the use of Hierarchical regression to analysed the stated objectives.

\section{Results and Discussion}

\subsection{Presentation of Respondents' Demographic Data}

This segment tends to discuss the result and findings through the use of questionnaires administered, 362 questionnaires were administered in which 284 were filled and submitted for analysis. The returned questionnaires represented like $75 \%$ of the entire sample size.

Table 1 which is the gender distribution shows $56.3 \%$ of the respondents were Male and $43.7 \%$ of the respondents were Female which implies most of the respondents are Male.

Considering the age distribution, it was shown that $25.0 \%$ of the respondents falls below 30 years of age, $45.1 \%$ of the respondent falls between $31-40$ years of age, and $29.9 \%$ of the respondent falls above 40 years and 
above thus implies that majority of the respondent falls between 31-40 years of age.

Furthermore, from Table 1 which is the marital status shows that $23.2 \%$ of the respondents were single, $67.6 \%$ of the respondents were married and $9.2 \%$ of the respondents were divorced thus imply majority of the respondent were married.

Similarly from academic qualification distribution, it was shown that $22.9 \%$ of the respondents were $\mathrm{OND} / \mathrm{NCE}$ holder, $48.9 \%$ of the respondents were HND/B.Sc holder, $24.6 \%$ of the respondents were MBA/M.Sc holder and $3.5 \%$ of the respondents acquire other qualification thus implies that majority of the respondent were HND/B.Sc holders.

Year of experience as depicted on Table 1 shows that $54.6 \%$ of the respondents falls below 5 years of experience while $45.4 \%$ of the respondent falls between $2-5$ years of experience, $44.2 \%$ of the respondent falls between 6-10 years of experience thus implies that majority of the respondent surveyed falls below 5 years of experience.

\begin{tabular}{|c|c|c|}
\hline Variables & Frequency & Percent \\
\hline \multicolumn{3}{|l|}{ Gender } \\
\hline Male & 160 & 56.3 \\
\hline Female & 124 & 43.7 \\
\hline Total & 284 & 100.0 \\
\hline \multicolumn{3}{|c|}{ Age Distribution } \\
\hline Below 30 & 71 & 25.0 \\
\hline $31-40$ & 128 & 45.1 \\
\hline Above 40 & 85 & 29.9 \\
\hline Total & 284 & 100.0 \\
\hline \multicolumn{3}{|c|}{ Marital Status } \\
\hline Single & 66 & 23.2 \\
\hline Married & 192 & 67.6 \\
\hline Divorced & 26 & 9.2 \\
\hline Total & 284 & 100.0 \\
\hline \multicolumn{3}{|c|}{ Academic Qualification } \\
\hline OND/NCE & 65 & 22.9 \\
\hline HND/B.Sc & 139 & 48.9 \\
\hline MBA/M.Sc & 70 & 24.6 \\
\hline Others & 10 & 3.5 \\
\hline Total & 284 & 100.0 \\
\hline \multicolumn{3}{|c|}{ Year of Experience } \\
\hline Below 5yrs & 155 & 54.6 \\
\hline $6-10$ & 129 & 45.5 \\
\hline Total & 284 & 100.0 \\
\hline
\end{tabular}

Source: Field survey, 2018

\subsection{Interpretation of Findings}

In order to investigate the influence of intrinsic reward on employee performance of Tertiary Institution Employee's in Ekiti State, a multiple regression analysis was conducted which led to the development of a model.

Table 2. A Summary of the Multiple Regression Analysis of the Interactive Influence of Intrinsic Reward on Employee Performance

\begin{tabular}{|l|l|l|l|l|}
\hline Model & $\mathrm{R}$ & $\mathrm{R}^{2}$ & Adjusted $\mathrm{R}^{2}$ & Std. Error of the Estimate \\
\hline 1 & .449 & .202 & .188 & .954 \\
\hline
\end{tabular}

$*_{\mathrm{p}}<0.05$

Source: Author's Computation using SPSS, 2018.

The model summary in Table 2 gives the $\mathrm{R}=0.449$ which is the multiple correlations of the five predictors and the employee performance. Again, the closeness of the $\mathrm{R}^{2}$ and adjusted $\mathrm{R}^{2}(0.202-0.188)$ which is $0.0141 .4 \%$ demonstrated the moderate positive significant relationship between the predictors variable and employee performance. i. e. it shows that there is moderate positive influence between intrinsic reward and employee performance. Also, this model is predicting $20.2 \%$ of the variance in employee performance using all predictors simultaneously; meaning that $20.2 \%$ of the variance in employee performance can be predicted from the intrinsic reward offer to the employee in Ekiti State Tertiary Institutions, which is the combination of Autonomy (ATM), Participatory Decision Making (PDM), Advancement (ACM), Promotion (PM) and Learning Opportunities (LO). 
Table 3. Multiple Regression Analysis Showing Significance of Predictors on Employee Performance

\begin{tabular}{|l|l|l|l|l|l|}
\hline Model & Sum of Square & Df & Mean Square & F & Sig \\
\hline Regression & 64.003 & 5 & 12.801 & 14.073 & .000 \\
\hline Residual & 252.870 & 278 & .910 & & \\
\hline Total & 316.873 & 283 & & & \\
\hline
\end{tabular}

$* \mathrm{p}<0.05$

a. Dependent Variable: Employee Performance (EP)

b. Predictors: (Constant), Autonomy (ATM), Participatory Decision Making (PDM), Advancement (ACM), Promotion (PM) and Learning Opportunities (LO)

Source: Author's Computation using SPSS, 2018.

Considering Table 3 , which is at 5 percent confident limit, F statistic revealed that the whole regression model is statistically significant in terms of its goodness of fit, which showed that intrinsic reward is capable of influencing employee performance of tertiary institutions in Ekiti State as showed by (F5, 283) $=14.073, \mathrm{P}<0.05$. Hence, this revealed that intrinsic reward of the tertiary institutions is capable of influencing employee performance.

Table 4. Multiple Regression Showing Contributions of Intrinsic Reward to Employee Performance

\begin{tabular}{|c|c|c|c|c|c|c|}
\hline \multirow{2}{*}{\multicolumn{2}{|c|}{ Model }} & \multicolumn{2}{|c|}{ Unstandardized Coefficients } & \multirow{2}{*}{$\frac{\text { Standardized Coefficients }}{\text { Beta }}$} & \multirow{2}{*}{$\mathrm{t}$} & \multirow{2}{*}{ Sig. } \\
\hline & & $\mathrm{B}$ & Std. Error & & & \\
\hline \multirow{6}{*}{1} & (Constant) & 1.853 & .302 & & 6.144 & .000 \\
\hline & No Supervision & .107 & .082 & .090 & 1.303 & .194 \\
\hline & Participation & .258 & .048 & .334 & 5.429 & .000 \\
\hline & Achievement & .156 & .074 & .157 & 2.108 & .036 \\
\hline & Promotion & .426 & .067 & .433 & 6.365 & .000 \\
\hline & Learning & .182 & .059 & .229 & 3.078 & .002 \\
\hline
\end{tabular}

Source: Author's Computation using SPSS, 2018

The Table 4 shows the contribution of each of the predictors. In this case, Promotion had highest contribution with Beta $=.426, \mathrm{p}<.05$ and $\mathrm{t}$-value $=6.365$, followed by Participatory Decision Making with value $=.258, \mathrm{p}<.05$ and $\mathrm{t}$-value $=5.429$, Learning Opportunities have Beta value $=.182, \mathrm{p}<.05$ and $\mathrm{t}$-value $=3.078$, Achievement have Beta value $=.156, p<.05$ and $\mathrm{t}$-value $=2.108$, While Autonomy on ground contributed less with Beta $=.107, \mathrm{p}<.05$ and $t=1.303$. All their contributions were statistically significant to Employee Performance. Hence, the null hypothesis is rejected. And we accept the alternative hypothesis.

\subsection{Discussion of Findings}

Findings showed that intrinsic reward is significant and positively related to employee performance among the tertiary institutions. This finding is consistent with the research carried out by Aktar, Sachu and Ali (2012) on the impact of rewards on employee performance in commercial banks of Bangladesh. In addition, the outcome of this study is ditto to the finding of Gohari, Kamkar, Olori and Edem (2017) examined the correlation between intrinsic reward strategies and employee performance in Microfinance banks in Nigeria. Again, these results are consistent with Khan, Shahid, Nawab and Wali (2013) who investigated the influence of intrinsic and extrinsic rewards on employee performance: the banking sector of Pakistan. Also, the findings of this study are in agreement with Azman and Mohd-Ridwan (2017) findings on performance-based reward administration enhancing employees' feelings of interactional justice in Malaysia. Similarly, Ahmed and Shabbir (2017) explored the effects of rewards on employee's performance in banks: a study of three districts (Lodhran, Vehari, Khanewal) Commercial Banks in Pakistan. In addition, it also identifies the impact of rewards system on employee performance.

From the results discussed above, it was found that all intrinsic reward variables were significant except autonomy with positive result but not significant. However, participation of employee in decision making of the organisation, achievement of university staff on the job, periodic staff promotion without delay and objectivity of the promotion and also, ensuring employees development through learning opportunities in developing their problem solving strength will significantly affect their performance and productivity to work and be committed to the institution.

\subsection{Summary and Implication of Findings}

It was shown that the entire variable intrinsic reward was positive and found significant on employee performance. On this basis, the alternate hypothesis was accepted while the null hypothesis was rejected. Therefore, tertiary institution should give priority to intrinsic reward for future purpose due to it psychological effect on human satisfaction and employee performance as to enhance organisation performance and effectiveness in the face of competition. This reward is also a transformational technique to develop human resources that can transform organisation and to manage effectively other resources of the organization. 


\subsection{Conclusion}

Based on the findings of this study, it was found that intrinsic reward constructs have a moderate significant effect on employee performance and extrinsic reward system has a moderate significant effect on employee performance all at 0.05 level of significance. From the findings, alternate hypothesis was accepted while null hypothesis was rejected thus concluded that intrinsic reward system is positively related to employee performance particularly among tertiary institutional workers in Ekiti State which is in accordance to the reviewed literatures in this study.

\subsection{Recommendations}

Consequent upon the findings, it is recommended that Government should ensure that there is adequate provision of teaching materials and infrastructural facilities which would enhance performance at work. Consequently, opportunities should be given to tertiary institution workers as to update their knowledge. The role of timely and objectivity of promotion can never be left out which is part of human advancement in the organisation. University management should also give autonomy to staff through involving them in decision that has to do with the organisation at large. Relevant educational agencies need to be set up to harmonize all intrinsic reward entitlements, staff developments and educational infrastructure to enhance their performance. However, since teaching is regarded as "mother of all profession", the treatment of the goose that lay the golden eggs should be above average and seen to command social respect and recognition from all and sundry.

Finally, it was found that reward system in public university has a greater value than that of private university thus recommended that private sector should also put in place the reward system that will relatively be commensurate with the effort put in by private institutional workers.

\subsection{Suggestion for Further Studies}

This study targeted employees of public and private Universities in Ekiti State. There could be different perceptions about reward system and employee performance in other tertiary institutions outside Ekiti State and other business sector as well. Therefore, further studies can be extended towards these areas highlighted.

\section{References}

Ahmed, I., \& Shabbir, S. (2017), “The Effects of Rewards on Employee's Performance in Banks: A Study of Three Districts (Lodhran, Vehari, Khanewal) Commercial Banks in Pakistan”, International Review of Management and Business Research, 6 (1), 352-361.

Ajmal, A, Bashir, M, Abrar, M, Khan, M. M., \& Saqib, S. (2015) "The Effects of Intrinsic and Extrinsic Rewards on Employee Attitudes; Mediating Role of Perceived Organizational Support”, Journal of Service Science and Management, 461-470.

Aktar, S., Sachu, M. K., \& Ali, E. M. D. (2012), “The Impact of Rewards on Employee Performance in Commercial Banks of Bangladesh: An Empirical Study", Journal of Business and Management, 6(2), 09-15.

Armstrong, M., \& Baron, A. (2005), "Managing Performance: Performance Management in Action", London, Chartered Institute of Personnel and Development.

Armstrong, M. (2012), “Armstrong's Handbook of Human Resource Management Practice”, New York, NY: Kogan Page Publishers.

Azman, I., \& Mohd-Ridwan, A. R. (2017), "Performance-Based Reward Administration Enhancing Employees' Feelings of Interactional Justice", Studies in Business and Economics, 12(1), 5-18.

Bosco, B. M. (2014), "Reward management practices and employee performance at Nakumatt holdings ltd", (Doctoral dissertation, University of Nairobi).

Deci, E. L. (1971), "Effects of Externally Mediated Rewards on Intrinsic Motivation”, Journal of Personality and Social Psychology, 18, 105-115.

Gohari, P., Ahmadloo, A., Boroujeni, M. B., \& Hosseinipour, S. J. (2013), "The Relationship between Rewards and Employee Performance”, Interdisciplinary Journal of Contemporary Research in Business, 5(3), 543570 .

Hackman, J. R., \& Oldham, G. R. (1976), "Motivation through the Design of Work: Test of a Theory", Organizational Behaviour and Human Performance, 16, 250-79.

Khan, I., Shahid, M., Nawab, S. \& Wali, S. S. (2013), "Influence of Intrinsic and Extrinsic Rewards on Employee Performance: The Banking Sector of Pakistan", Academic Research International, 4(1), 282-291.

Kotelnikov, V. (2010), "Reward Systems \& Reward Motivation (Effective Reward Systems: Increasing Performance \& Creating Happier Employees)", Retrieved from: http:/www.1000ventures.com/businessguide/crosscuttings/motivating-reward- system.html.

Maund, L. (2001), "An Introduction to Human Resource Management Theory \& Practice", Palgrave, Macmillan. Njanja, W. L., Maina, R. N., Kibet, L. K., \& Njagi, K. (2013), "Effect of Reward on Employee Performance: A Case of Kenya Power and Lighting Company Ltd., Nakuru, Kenya", International Journal of Business and Management, 8 (21), 41-49. 
Ripley, D. (2008), “Improving Employee Performance”, International Journal of Human Resource Management, $17(1), 26-35$.

Shields, J., Brown, M., Kaine, S., Dolle-Samuel, C., North-Samardzic, A., McLean P., \& Plimmer, J. R. (2015). Managing Employee Performance and reward. (2 $2^{\text {nd }}$ ed.): United Kingdom.

Stoner, J. A. F., \& Freeman, S. (1992), “Management”, Prentice Hall of India. New Delhi.

Torrington, D., Hall, L., \& Stephen, T. (2008), "Human Resource Management” (7 $7^{\text {th }}$ Ed.). Edinburg: Pearson Education Limited.

Wambugu, S. M., \& Ombui, K. (2013), "Effects of Reward Strategies on Employee Performance at Kabete Technical Training Institute, Nairobi, Kenya", Public Policy and Administration Research, 3 (7), 19-46.

Williamson, I. O., Burnett, M. F., \& Bartol, K. M. (2009), "The Interactive Effect of Collectivism and Organizational Rewards on Affective Organizational Commitment", Cross Cultural Management: $A n$ International Journal, 16, 28-43.

Wilson, B. T. (2003), “Innovative Reward Systems for the Changing Work Place. New York: McGraw

Hill”, Retrieved from http://books.google.co.ke/books?id=qRBSya4773AC.

Yamane, T. (1967), “Elementary Sampling Theory”, Englewood Cliffs: Printice hall.

Modupe Olayinka Ajayi is a Fellow of a number of professional bodies including: Civilian Institute of Democratic Administration (CIDA), Ghana; Nigeria Institute of Management; Institute of Human \& Natural Resources; Institute of Public Administration of Nigeria; Institute of Corporate Administration of Nigeria. This is in addition to being a member of Universities Human Resource, Britain; Institute of Industrialists \& Corporate Administrators; Research Board of Advisors; American Biographical Institute; Association of Commonwealth Universities; Forum for African Women Educationist (FAWE) among others. She obtained her Bachelor of Arts (Ed.) in English from University of Benin, Benin-City, Masters in Public Administration from Obafemi Awolowo University, Ile-Ife and Ph.D. in Management Science from The Federal University of Technology, Akure all in Western Nigeria in 1985, 1991, and 2000 respectively. She served as the Registrar of The Federal University of Technology, Akure between 2011 and 2017 and currently a Senior Lecturer in the Department of Project Management Technology in the same institution. She has several publications to her credit onshore and offshore. Her research interest is in the area of Human Resource Management and Gender . 